\title{
Experimental and numerical analysis of cylindrical laminated glass shells
}

\section{Silindirik lamine cam kabuk yapıların deneysel ve sayısal çözümlemesi}

\author{
Ebru DURAL $1^{*}$
}

1Department of Civil Engineering, Engineering Faculty, Adnan Menderes University, Aydın, Turkey. ebrudural@gmail.com

\section{Abstract}

Laminated glass is a kind of safety glass which consists of two glass layers with an interlayer Polyvinyl Butyral (PVB) in between them. Even if the breaking happens, the glass layers are held together by the $P V B$ interlayer and minimize the risk of injury. Laminated glass units have long been used in the transportation and automotive industries. Because of their resistance to a wide range of loading and environmental condition, nowadays they are extensively used in architectural glazing products Laminated glasses display highly complicated structural behavior because they can easily perform large displacement since they are very thin and there is a big difference between the material properties. Because of mathematical complexity and discontinuous stress distributions of laminated glass units most of the studies are about linear behavior rather than nonlinear behavior of the laminated glass units. In the current study, a finite element model is developed for the analysis of cylindrical laminated glass shells and experimental studies are carried out for the validation of model. It is observed from the figures presented, numerical results and experimental results from the tests are in good agreement.

Keywords: Laminated glass, Cylindrical shell, Nonlinear behavior, Experimental analysis, Finite element method

\section{Introduction}

Laminated glass units are constructed by placing a thin elastomeric interlayer, usually polyvinyl butyral, between two glass layers. The layers are connected each other with a process at high temperature and pressure in autoclave referred to as lamination. Cross-section of laminated glass unit is displayed in Figure 1. They have been used in the transportation and automotive industries for a long time. In recent years they are extensively used in architectural glazing products because of their properties like safety, security, sound control, ultraviolet screening, solar energy control, durability, protection from bomb blast and natural disasters like hurricane, earthquake, etc. When laminated glasses are broken, the polyvinyl butyral interlayer keeps the glass shards together and help to provide protection from injury, and prevents property damage from man-made and natural disasters. The interlayer is also advantageous in other aspects. Because of shear damping performance of the PVB, laminated glass is very effective in controlling the sound. Solar control can also be accomplished by the ability of interlayer to reflect and/or absorb and re-radiate much of the solar UV radiation. Through the mentioned advantageous of laminated glass, the use of it have increased in contemporary building architecture. But prediction of real behavior real behavior of laminated glass unit is hard compared with other structural materials because of the combination of with a flexible and soft material PVB with a brittle and hard material glass. Because of the lack
Öz Lamine cam polivinil butiral (PVB) ara tabaka ile birbirine bağlanmıs iki cam tabakadan oluşan emniyet cam türüdür. PVB ara tabaka, kirllma olsa bile cam tabakaları bir arada tutar ve yaralanma riskini en aza indirir. Uzun yillardır ulaşım ve otomotiv endüstrilerinde kullanılmakta olan lamine cam birimler yük ve çevresel koşullara gösterdikleri büyük dirençler nedeniyle, günümüzde yaygın olarak mimari cam ürünlerinde kullanılmaktadırlar. Lamine camlar oldukça karmașık mekanik davranıs gösterirler çünkü çok ince oldukları için kolayca büyük yer değiştirmeler gösterirler ve malzeme özellikleri arasında büyük bir fark vardır. Lamine cam ünitelerin matematiksel karmaşıklıkları ve süreksiz gerilme dağılımları nedeniyle, çalışmaların çoğu lamine cam birimlerinin doğrusal olmayan davranışı yerine doğrusal davranıșları ile ilgilidir. Bu çalıșmada, silindirik lamine cam kabukların çözümlenmesi için sonlu elemanlar modeli geliştirilmiş ve modelin doğrulanması için deneysel çalıșmalar yürütülmüștür. Sunulan grafiklerden gözlendiği gibi sayısal sonuçlar ve deneylerden elde edilen sonuçlar uyum içerisindedir.

Anahtar kelimeler: Lamine cam, Silindirik kabuk, Doğrusal olmayan davranıș, Deneysel analiz, Sonlu elemanlar yöntemi

of information about the structural behavior, construction details and technological properties of laminated glass units some of the glass structures have failed in service in the last years.

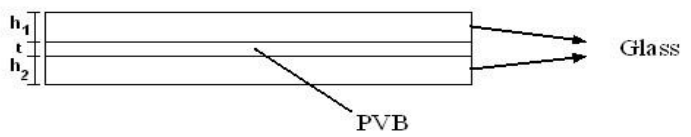

Figure 1: Laminated glass.

Behavior of the laminated glass units is highly nonlinear because of two different types of materials, glass and PVB. The modulus of elasticity of a glass is about 70000 times greater than that of polyvinyl butyral. As it is known the laminated glass unit is very thin and can easily undergo large displacements as much as about six times of the thickness of the unit.

Laminated glasses have become more and more important element in modern-day construction industry. Despite the complex mechanical behavior of laminated glass, studies concerned with the structural performance of laminated glass unit are increasing and increasing. In the literature there are many studies about the behavior of laminated glass units.

Because of the complex mechanical behavior of laminated glass units, most of the studies done by researchers on 
laminated glass units are experimental [1]-[4]. Hooper [1] and Behr [2]-[4] conducted experimental studies.

Theoretical studies about the structural behavior of laminated glass units are limited. But in the past decades many researchers have tried to model laminated glass behavior using numerical methods [5]-[10].

A new mathematical model is improved units by Vallabhan et al. [5] for the nonlinear analysis of laminated units. To verify the results they conducted experiments. Asik [6] improved Vallabhan's model [5] by using modified strongly implicit procedure (MSI) to provide less calculation time and to avoid storage of full matrix that need large memory. In 2005 Asik and Tezcan [9] improved a mathematical model to analyze laminated glass beams under large deflections. They verified their model by using the experimental data obtained from the experiments and using the data obtained from the finite element model. Shell structures have great importance in engineering but studies about nonlinear behavior of shell structures are limited in the literature [11]-[15].

Schimmels and Plazatto [11] analyzed the geometrically nonlinear behavior of the laminated shell geometry by using orthogonal curvilinear coordinates. They applied transformation between Cauchy and Lagrangian coordinate systems for isotropic and composite shells. Using nonlinear strain displacement relations and minimum potential energy theory nonlinear algebraic equations were obtained for displacements. To solve the nonlinear equations they were converted to linear equations and finite element method was used to solve these equations. They verified their model by using the results of Sabir [12]. It is observed that the fiber rotations became large enough to affect the material transformation matrix when the shell displacement reached three times of the shell thickness.

Hughes and Liu [14] presented a nonlinear finite element model for the three dimensional quasi static analysis of shell structures. They considered large strains and rotation effects in their analysis.

Kuo-Mo [15] developed a geometrically nonlinear model for the analysis of shell structures using flat triangular shell elements. Their model is based on updated Lagragian description of motion. Direct and incremental methods were used to calculate the total deformational rotations. For the verification of the results numerical studies based on Newton Raphson method were performed.

Dural [16] developed a mathematical model to analyze the performance of laminated glass curved beams and cylindrical shells. The total potential of the unit was written in terms of displacements and the governing differential equations were obtained via variational approach and minimum potential energy theorem. The nonlinear equations were converted from continuous form to discrete form by using finite difference method. For the validation of model the results of developed finite element model and experiments in the literature were used.

According to the authors' knowledge there is not any study regarding the nonlinear behavior of cylindrical laminated glass shells in the literature. Therefore, the study on the nonflat laminated glasses is considered to be crucial since they are already in use. In the present study, experimental and numerical analyses by FE-modeling in ABAQUS are carried out in order to gain a deeper knowledge about the behavior of laminated glass cylindrical shell since these units are used in modern-day construction, and to authors' knowledge, there is not any significant research done on the laminated glass shells, too. Corresponding finite element numerical model is developed in the software ABAQUS to predict the behavior of the unit and to calculate the displacements and stresses. The results obtained from the experimental study are compared with the corresponding FEM results and pronounced conclusions are obtained.

\section{Finite element modeling and experimental study}

Shell structures are the load carrying elements which have a great importance in engineering and in particular, in civil, mechanical, architectural and marine engineering. Large span roofs, water tanks, concrete arch domes, liquid retaining structures are examples of shell structures. A shell is said to be a curved structural element whose thickness is small when compared with the other dimensions of shell and with its radius of the curvature. Examples of the shell structures include pipes, pressure vessels, roofs, dooms, sheds, airplane wings, car sheds, turbine disks and bulkheads.

In this study, experimental and numerical studies are carried out on the cylindrical laminated glass shells. Cylindrical laminated shell unit and reference axes that are considered in this study are shown in Figure 2.

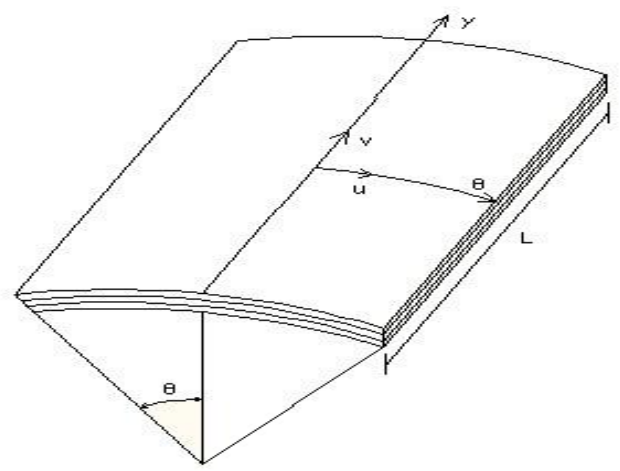

Figure 2: Cylindrical laminated glass shell.

As the first step of the study, finite element model is developed. The finite element analysis is carried out using commercial finite element software ABAQUS. The threedimensional model, developed for the finite element method, is solved with ABAQUS version 6.13. The unit is consisting of two glass shells, and each of them has a thickness of $2.5 \mathrm{~mm}$. The thickness of the inner core is $0.76 \mathrm{~mm}$. Each part of the laminated glass unit is created as deformable solid in 3-D modeling space through extrusion. Each section of the unit is created as solid and homogenous. Concentrated load is applied to the midpoint of the outer surface of the unit. Eight node linear brick element (C3D8R) is used in meshing since it gives more accurate results and leads to faster convergence where large deformations are involved. To obtain convergence, the unit is divided to 300 elements in radial and axial directions. To achieve perfect bound between the layers the surfaces constrained to each other using tie option. The layers of the unit are modeled separately and then joined face to face with convenient constraint conditions for the corresponding nodes on the layers of the unit. The elasticity modulus of glass is 64.5 $\mathrm{GPa}$. Shear modulus of interlayer is taken as $1000 \mathrm{kPa}$. 
Poisson's ratio of glass and interlayer are taken 0.3 and 0.29 , respectively To perform large deformation analysis "geometric nonlinearity" option is used. In order to create the hinged boundary conditions, radial and circumferential degrees of freedom of all nodes at the boundaries of the laminated unit are set to be zero. Because of symmetry, only a quarter of the shell is considered in the developed finite element model. For the case of free-hinged supported shell subjected to concentrated load, the pictorial presentation of boundary conditions of the modeled cylindrical shell are plotted in Figure 3. Thus the boundary conditions are as follows:

Boundary Condition along the centerline $\theta=0$

$\frac{\partial \mathrm{v} 1}{\partial \theta}=0, \frac{\partial \mathrm{v} 2}{\partial \theta}=0, \mathbf{u} 1=0, \mathbf{u} 2=0$, Symmetry

Boundary Condition along the edge $\theta=\theta_{1}$

$\mathrm{u} 1=0, \mathrm{u} 2=0, \mathrm{v} 1=0, \mathrm{v} 2=0, \mathrm{w}=0, \frac{\partial^{2} \mathrm{w}}{\partial \theta^{2}}=0$

Boundary Condition along the centerline $y=0$

$$
\frac{\partial \mathrm{u} 1}{\partial \theta}=0, \frac{\partial \mathrm{u} 2}{\partial \theta}=0, \mathrm{v} 1=0, \mathrm{v} 2=0, \text { Symmetry }
$$

Boundary Condition along the edge $y=y_{1}$

\section{Free}

where $w$ is the radial displacement, $u_{1}$ and $u_{2}$ are the circumferential displacements of the top and bottom glass layers, respectively, $v_{1}$ and $v_{2}$ are the axial displacements of top and bottom glass shells, respectively.

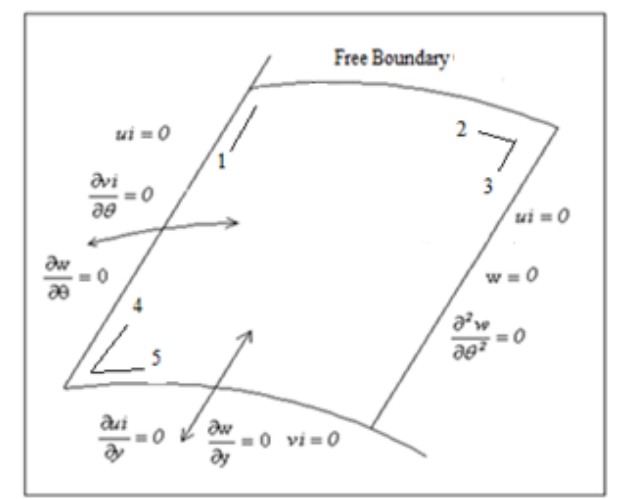

Figure 3: Pictorial presentation of boundary conditions and locations and numbering of the strain gauges for the free-

hinged supported cylindrical laminated glass shell.

In order to validate, above calculated results by Finite Element Model some experimental tests on the behavior of laminated glass cylindrical shell were performed. Three point bending tests were performed in order to define mechanical behavior of laminated glass shell unit by determining the deflections, stresses and the corresponding strains for various loading conditions. 4 test specimens were supplied by Dora Glass Company. Laminated glass shell tested had $0.36 \mathrm{~m}$ length in $\mathrm{y}$ direction, the arc length of the unit $0.58 \mathrm{~m}$ and the radius of the shell unit was $0.925 \mathrm{~m}$. Laminated unit was consisting of two glass shells, and each of them had a thickness of $2.5 \mathrm{~mm}$. The thickness of the inner core was $0.76 \mathrm{~mm}$. The total thickness of the unit was $5.76 \mathrm{~mm}$. The experiments were carried out at Middle East Technical University in the
Engineering Sciences Department. Tests were performed using universal material testing machine Lloyd Inst. Ltd. LR50K (Lloyd Instruments, UK) in order to test the compressive strength of units. The material testing machine Lloyd Inst. Ltd. LR50K was connected to computer with material test and control software NEXYGEN 2.0 software which offers possibility of automatically transferring the test results directly into computer. Four strain gauges with 120 $\mathrm{Ohm}$ and $5 \mathrm{~mm}$ length were used and placed on the laminated glass cylindrical shell. By taking advantage of the symmetry of the complete experimental setup, the strain gauges were placed at four strategic location on both sides of one quadrant of the unit. While the strain gauge at the center was located to the bottom surface of unit, the strain gauges at the corner and at the free edge were located to the top surface of the unit. Two strain gauges were located to the corner of the unit in horizontal and vertical directions while the strain gauge at the free edge was located in vertical direction. Strain gauges were located $2.5 \mathrm{~cm}$ away from the edges. Pictorial presentation of location and numbering of strain gauges can be seen from Figure 3. Temperature of the laboratory was between 22-23 ${ }^{\circ} \mathrm{C}$, and humidity was between $25-28 \%$. Three wire quarter bridge arrangement was used to measure the strain values because temperature changes in the lead wire system would introduce errors into measured strain data, if two wire connection was used. Due to the nature of the free-hinged supported cylindrical shell setup, the unit was left free along the curved edge and restrained along the straight edge in the theta and radial directions. Along the two straight edges of the unit, circumferential deflection $(u)$ and radial deflection $(w)$ were zero and rotation was free. The 4-channel strain measurements were completed by using FLA-5-11 type strain gauges and a Portable Strain Indicator (Vishay Measurement Group, USA). The KFG-5-120-C1-11N2C2 strain gauges (gauge

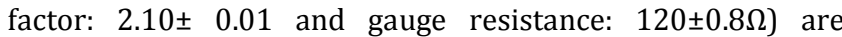
products of, Kyowa Electronic Instruments Co., Ltd., Japan.

Load was applied to the center of the glass unit. For test setup $90 \mathrm{~N}$ was the target force. Within the range of force that tests were conducted, test specimens were within the elastic limit giving us the possibility to repeat tests by using the same test specimens. At each setup condition, speed of the material testing machine was set at $2 \mathrm{~mm} / \mathrm{min}$ which is enough to reach the target quality. 1 minute after reaching the target value for the force, data were collected from strain gauges and from the material testing machine. Data were collected and saved using 4 channel strain gauge indicator. The value of maximum deflection was obtained using material testing machine. In Figure 4 the apparatus and setup used to conduct tests for the laminated glass cylindrical shell are presented.

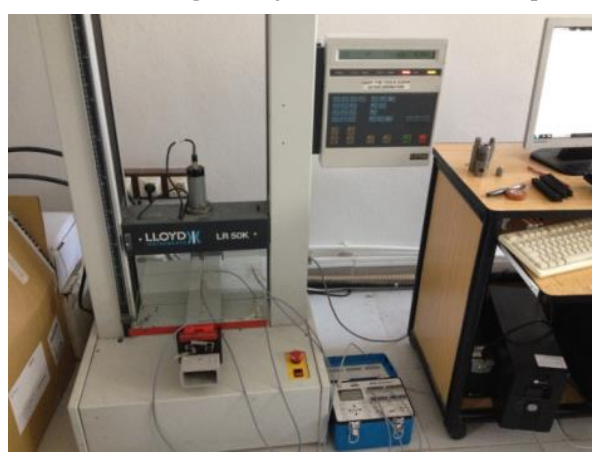

Figure 4: Experimental setup for the cylindrical laminated glass shell. 


\section{Results}

To validate the developed finite element model, results obtained from the analysis are compared with the results of conducted experiments. Experimental stress and displacement results obtained from the conducted tests are compared with those obtained from the finite element model and presented in Table 1 and Figures 5 and 6. Deflections obtained from the finite element model are higher than those obtained from experiment. Figure 5 and Table 1 show that deflection values for 10 and $20 \mathrm{~N}$ loadings, which are the first two load values in the testing, are not only considerably above the results of mathematical model but also have errors about $16 \%$ and $11 \%$ respectively. Generally, this may be due to an error in measurement or the placing of a strain gauge. In present situation, most probably, it is resettlement of the test specimen due to the gaps formed by the misplacement of specimens since those values are measured at the beginning of the testing. For the rest of the displacement data the results are in good agreement.

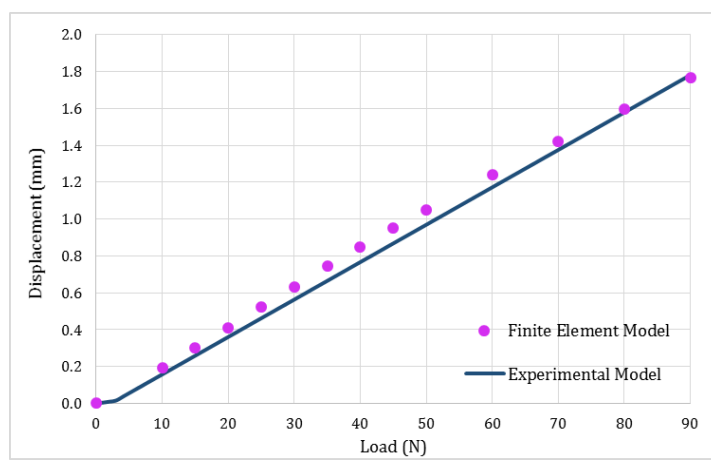

Figure 5: Central deflection comparison for experimental and finite element model results.

Comparison of stresses at the center is presented in Figure 6 and Table 1. Throughout the study, compression stress is considered as negative and tension stress is considered positive. At bottom surface of laminated unit stresses occur as tension. It is observed that the stresses in the finite element model and experimental model are quite close to each other; however, the maximum difference is nearly $10 \%$ at most. It is clear that the finite element model predicts the maximum stresses with very small errors. Results predicted by finite element model and measured from the experiment show little difference in higher loads.

Table 1: Comparison of results for the laminated cylindrical shell.

\begin{tabular}{ccccccc}
\hline & \multicolumn{3}{c}{ Maximum Stress $\left(\mathrm{N} / \mathrm{cm}^{2}\right)$} & \multicolumn{3}{c}{ Displacement $(\mathrm{mm})$} \\
\cline { 2 - 7 } $\begin{array}{c}\text { Load } \\
\text { N }\end{array}$ & Experiment & Model & $\begin{array}{c}\text { Percentage } \\
\text { Error }\end{array}$ & Experiment & Model & $\begin{array}{c}\text { Percentage } \\
\text { Error }\end{array}$ \\
\hline 0 & 0 & 0 & 0 & 0 & 0 & 0 \\
10 & 1.635 & 1.520 & -7.57 & 0.162 & 0.193 & 15.75 \\
20 & 2.967 & 2.776 & -6.88 & 0.366 & 0.411 & 10.84 \\
30 & 4.830 & 5.426 & 10.98 & 0.578 & 0.634 & 8.94 \\
40 & 6.510 & 7.145 & 8.89 & 0.772 & 0.848 & 9.00 \\
50 & 8.330 & 8.807 & 5.42 & 0.972 & 1.050 & 7.38 \\
60 & 10.150 & 10.420 & 2.59 & 1.173 & 1.241 & 5.46 \\
70 & 12.110 & 11.990 & -1.00 & 1.376 & 1.423 & 3.29 \\
80 & 13.860 & 13.390 & -3.51 & 1.579 & 1.596 & 1.05 \\
90 & 15.400 & 15.01 & -2.60 & 1.782 & 1.765 & -0.97 \\
\hline
\end{tabular}

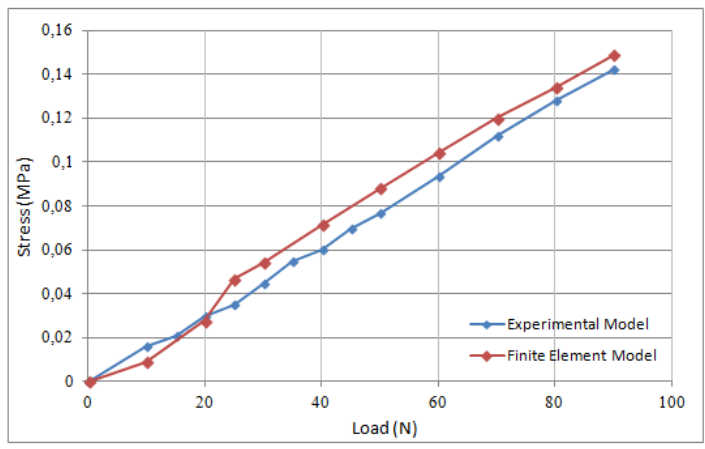

Figure 6: Stress-load relation for free-hinged supported shell readings from the strain gauges 4-5 and finite element model.

To determine the effect of the PVB interlayer on the behavior of a laminated glass unit, strains are measured at various locations in both sheets. Strain gauges are used to measure strains at five different locations. Stress values of free- hinged supported cylindrical laminated glass shell at the corner and at the boundary of unit which are obtained from readings of strain gauge 1, 2 and 3 are given in Figure 7. Strain gauges 1, 2 and 3 are located at top surface of the unit. At top surface of laminated glass unit stresses developed as compression.

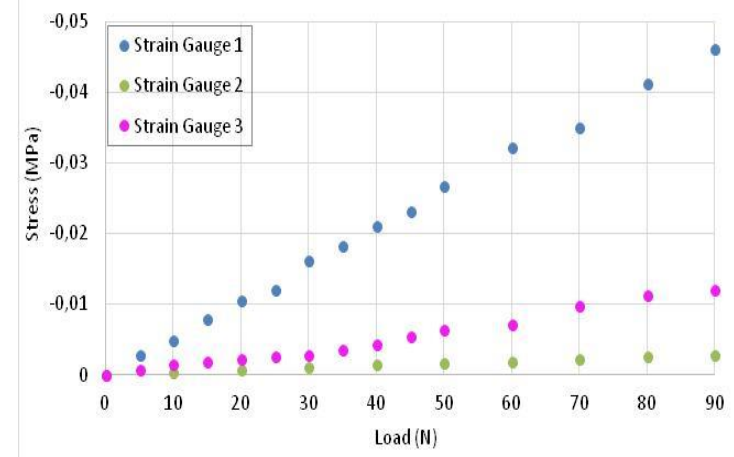

Figure 7: Stresses versus load at corner and edge of unit (Strain gauges 1, 2, 3).

Figure 8 and 9 represent the radial deflection of top glass unit along the centerline in y and $\theta$ direction, respectively. As can be seen from figures radial deflections take their maximum value close to the center of unit. Radial deflections are zero at the edge of the unit in accordance with the geometry of shell unit. The sign of radial deflections along $\theta$ direction changes $10 \mathrm{~cm}$ away from the center of unit. Deflections along the $y$ direction are positive along the line.

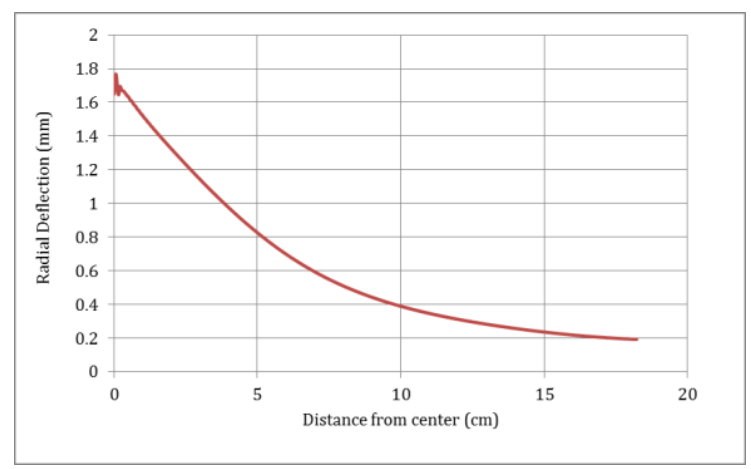

Figure 8: Radial deflections of top glass unit along the centerline at $\theta=0$. 


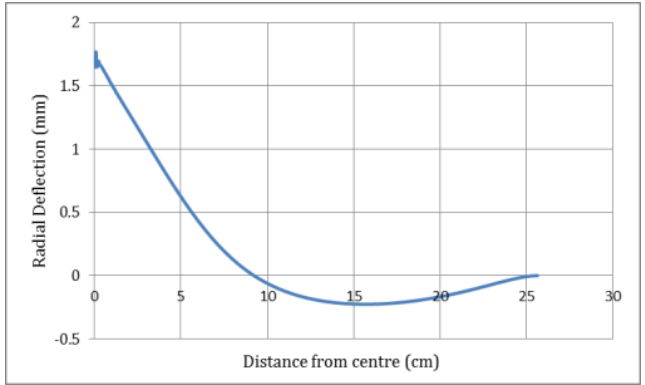

Figure 9: Radial deflections of top glass unit along the centerline at $y=0$.

Axial deflections in y direction take their maximum value at the center of the unit while they are zero at the hinged boundary as can be seen from Figures 10 and 11 .

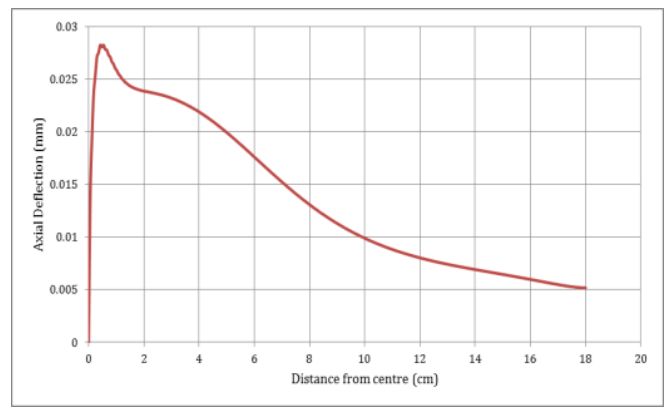

Figure 10: Axial deflections of top glass unit along the centerline at $\theta=0$.

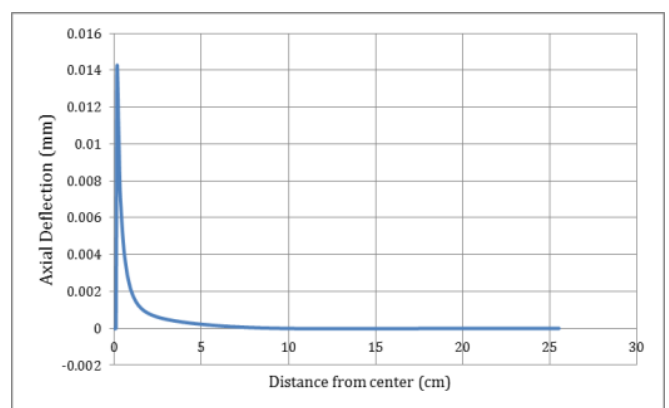

Figure 11: Axial deflections of top glass unit along the centerline at $y=0$.

Figures 12 and 13 are plotted to consider the stresses at the top glass unit along y and $\theta$ direction, respectively. Stresses are both tension and compression along the centerlines of the unit. As can be seen from figure while they are tension close to the center of the unit, they are in compression in other parts of the unit.

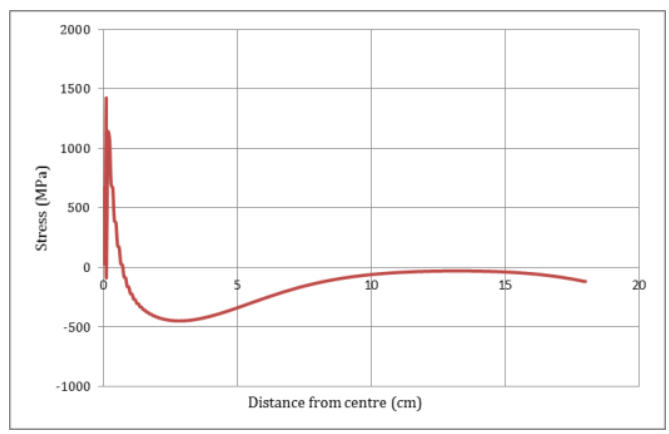

Figure 12: Stresses of top glass unit along the centerline at $\mathrm{y}=0$.

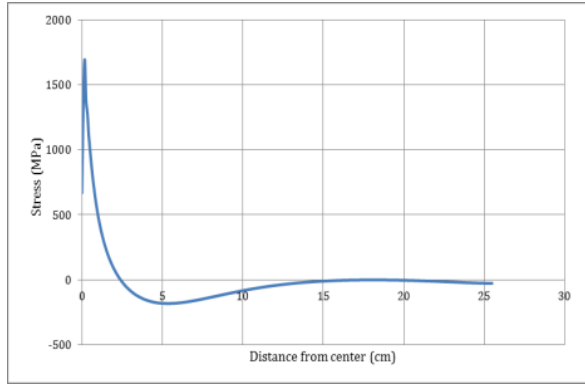

Figure 13: Stresses of top glass unit along the centerline at $\theta=0$.

Because of symmetry only a quarter of the unit is solved. View of circumferential, radial displacements and the axial displacements in y-direction for applied $90 \mathrm{~N}$ on the top and bottom glass surfaces are shown in Figures 14, 15 and 16. As it can be seen from Figure 14 circumferential displacements take both positive and negative values. Circumferential displacements take their maximum value close to the center of the unit.

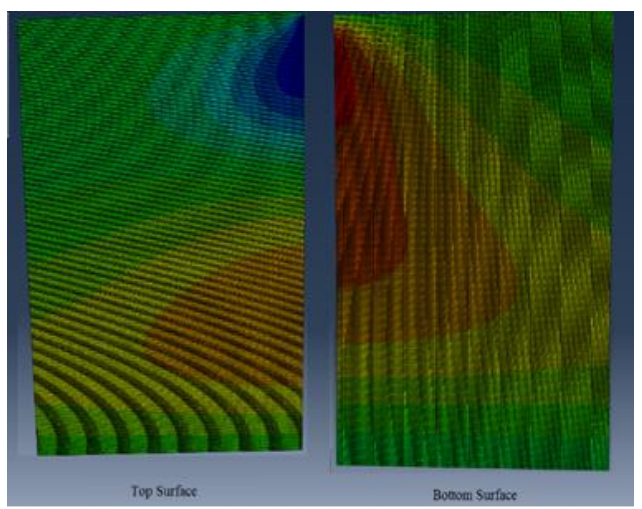

Figure 14: Circumferential Displacement $(u)$ contours of top and bottom glass surfaces in the $\theta$ direction.

Figure 15 is plotted to show radial displacement contours of top and bottom glass surfaces. It is observed from figure 15 that they take their maximum value in negative $y$-direction at the center of the unit because of the applied concentrated load is in downward direction. The radial deflection contours are nearly same on the top and bottom glass surfaces.

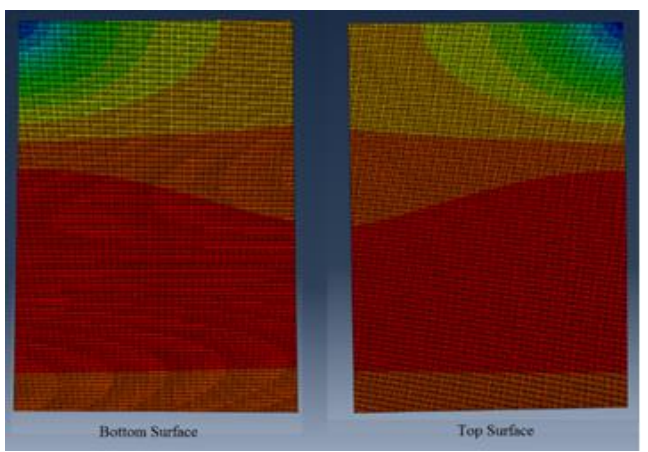

Figure 15: Radial Displacement $(w)$ contours of top and bottom glass surfaces.

Figure 16 illustrates axial displacement (v) contours for the bottom and top glass surface in the $y$-direction. Axial displacements take their maximum value close to the center of the unit as negative. Figure 17 is plotted in order to have detailed information about the contour of maximum principal 
stress for the quarter of the shell. While the stresses at the center of the unit are in compression on top glass surface, they are in tension on the bottom surface of the unit.

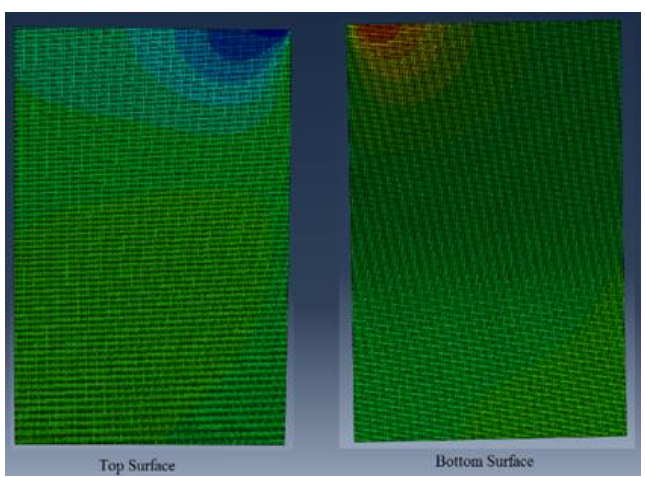

Figure 16: Axial displacement $(v)$ contours for the bottom and top glass surface in the y direction.

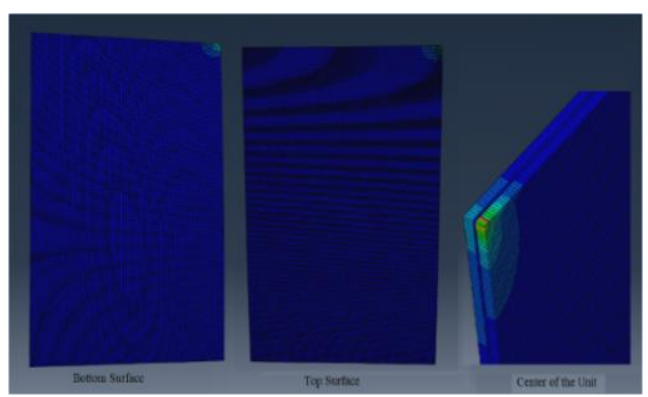

Figure 17: Maximum principal stress contours for the bottom and top glass surface.

\section{Conclusions}

In order to examine the behavior of the cylindrical laminated glass shell a finite element model is developed and solved by using finite element package program ABAQUS and an experiment is conducted. The boundary conditions are placed as free along the curved edges and restrained along the straight edges in y-direction and the load is applied at the center of the unit. The comparison of results obtained from the experimental model and finite element model on laminated glass cylindrical shell are matching quite well. The difference between the results is nearly $11 \%$ at most. To repeat experiments using the same glass specimens, force is applied within elastic limit. As a result of study stress and displacement functions of the cylindrical laminated glass shell are given for the use of engineers in order to determine the strength and behavior of the cylindrical laminated glass shells.

\section{References}

[1] Hooper JA. "On the bending of architectural laminated glass". International Journal of Mechanical Sciences, 15, 309-323, 1973.
[2] Behr RA, Minor JE, Linden MP, Vallabhan CVG. "Laminated glass units under uniform radial pressure". Journal of Structural Engineering, 111(5), 1037-1050, 1985.

[3] Behr RA, Minor JE, Norville HS. "Structural behavior of architectural laminated glass". Journal of Structural Engineering, 119(1), 202-222, 1993.

[4] Behr RA, Linden MP, Minor JE. "Load duration and interlayer thickness effects on laminated glass". Journal of Structural Engineering, 112(6), 1441-1453, 1986.

[5] Vallabhan CVG. "Iterative analysis of rectangular glass plates". Journal of Structural Engineering, 109(2), 489-502, 1983.

[6] Vallabhan CVG, Das YC, Magdi M, Asik MZ, Bailey JR. "Analysis of laminated glass units". Journal of Structural Engineering, 119(5), 1572-1585, 1993.

[7] Asik MZ, Vallabhan CVG. "On the convergence of nonlinear Plate Equations". Computers and Structures, 65(2), 225-229, 1997.

[8] Asik MZ. "Laminated glass plate: revealing of nonlinear behavior". Computers and Structures, 81, 2659-2671, 2003.

[9] Asik MZ, Tezcan SA. "Mathematical model for the behavior of laminated glass beams". Computers and Structures, 83(21-22), 1742-1753, 2005.

[10] Asik MZ, Dural E, Yetmez M, Uzhan T. "A mathematical model for the behavior of laminated uniformly curved glass beams". Composites Part B: Engineering, 58, 593-604, 2014.

[11] Schimmels SA, Palazotto AN. "Nonlinear geometric and material behavior of shell structures with large strains". Journal of Engineering Mechanics, 120(2), 320-345, 1994.

[12] Sabir AB, Lock AC. "A curved cylindrical shell finite element". International Journal of Mechanical Sciences, 14, $125,1972$.

[13] Ashwell DG, Sabir AB. "A new cylindrical shell finite element based on simple independent strain functions". International Journal of Mechanical Sciences, 14, 171-183, 1972.

[14] Hughes JRT, Liu WK. "Nonlinear finite element analysis of shells: Part I. three dimensional shells". Computer Methods in Applied Mechanics and Engineering, 26(3), 331-362, 1981.

[15] Kuo-Mo H. "Nonlinear Analysis of general shell structures by flat triangular shell element". Computers and Structures, 25(5), 665-675, 1987.

[16] Dural E. Analysis of Laminated Glass Arches and Cylindrical Shells. Ph.D. Thesis, Middle East Technical University, Ankara, Turkey, 2011. 